\title{
FORMATION OF STUDENTS COMMUNICATIVE COMPETENCE IN THE PROCESS OF CONTINUOUS EDUCATION
}

\section{Saminjon Sobirovich Evatov}

Lecturer Department of Pedagogy, Fergana State University

\section{ABSTRACT}

This article discusses the need to develop students' communicative competence in the process of continuing education, as well as the concept of communicative competence, personal success, competitiveness, high professional training.

KEYWORDS:- Education, learner, approach, professional skills, communicative competence, competence, development, formation.

\section{INTRODUCTION}

Decree of the President of the Republic of Uzbekistan No. PD-4947 of February 7, 2017 "On the Strategy for further development of the Republic of Uzbekistan" Improving the quality and efficiency of higher education institutions based on the introduction of international standards for the assessment of the quality of education and training, the gradual increase in quotas for admission to higher education institutions, the promotion of research and innovation, Tasks such as the creation of effective mechanisms for the implementation of innovation achievements [1] have been identified. In order to ensure the fulfillment of these tasks, it is important to develop the professional training of future professionals through the formation of communicative competence in the educational process.

The ability to communicate effectively, which we call communicative competence today, has always fascinated many scholars. In the disciplines of linguistics, sociology, social psychology, pedagogy and other modern fields of knowledge, attention is paid to the theoretical study of interpersonal relationships, communicative behavior of the individual. However, it is also necessary to study in practical terms a person's speech readiness in performing social functions. The concept of communicative competence developed in this direction, in our opinion, helps to connect social and humanitarian knowledge with the formation and 
development of students' competent communication skills in all life processes and, therefore, their practical efforts to perform social functions. Accordingly, the importance of scientific recommendations that can be taken into account in the implementation of various educational reforms, in particular, the transition of the education system to new state standards and the training of future professionals is growing..

The main goal of the modern educational process is to develop the personal and professional abilities, knowledge, skills and competencies of the learners. In the process of continuing education, it is necessary to form the communicative competence of students, they have not only general secondary knowledge, but also the ability to positively solve problems in various fields and activities.

The experience of educational reforms in our country shows that the development of the most socially important qualities of a person: communication, responsibility, initiative, creative approach to business, decision-making is relevant today. The formation of such qualities in future professionals will allow them to carry out quality activities effectively in the future. The problem is that for professions related to increasing speech responsibility, high-quality effective communication, the ability to master the word, to teach to solve professional problems using the word. The purpose of our research is to identify and theoretically substantiate the pedagogical conditions necessary for the development of communicative competence of students of technical higher education institutions in the teaching of pedagogical disciplines.

Object of research the process of developing students' communicative competence in the study of social sciences in the process of continuing education.

\section{Materials AND METHODS}

The importance of developing students' professional skills through the formation of communicative competence in the process of continuing education has been studied by a number of scholars. In particular, the ability to communicate effectively, which we today call communicative competence, has always been in the spotlight of professionals. Well-known scientist NA Muslimov emphasizes [2] that in order to effectively implement modern personcentered educational technologies, students must have the necessary communicative competence, flexibility in the process of interaction in the educational process, the use of communicative technologies. students and the teacher are required to understand each other when applying.

Pedagogical scientist Sh.S.Sharipov [3] The professionalism of a teacher in the system of continuing education is determined not only by the set of knowledge and skills, but also by the effectiveness of their application in real teaching practice. Competence means ability, the ability to mobilize existing knowledge and experience to solve a problem in certain situations.

F.E. Zeer [4] from the Commonwealth states that a favorable moral and spiritual environment in the educational process, humanism and democratization of communication with students, the effectiveness of interaction, the effectiveness of problem solving, teacher and student satisfaction depends in many ways on the communicative competence of the teacher $\mathrm{He}$ admits that

MU Lukyanova [5] The main concept is the structure of knowledge, skills and abilities is competence. Competence reflects the current trends in understanding the results of the learning process and the requirements for professional activity, and states that it is 
necessary to describe the process of assessing the quality of education and to ensure its improvement.

The authors emphasize the problems of developing students' communicative competence in the study of social sciences in the process of continuing education, the search and implementation of methods that take into account the specifics of the humanities, a new interactive dialogue aimed at activating the humanities, including psychological and pedagogical emphasize the need to look for forms.

However, despite the development of theoretical and methodological support for the introduction of a competency-based approach in continuing education, the pedagogical conditions for the future development of universal, including communicative competence, have not been identified.

Competence is a real, formed personal quality based on knowledge, an intellectual and personally defined social and professional formation of a person. Competence is a set of interrelated characteristics (knowledge, skills, methods of activity) that are identified in relation to specific objects and processes and are required for high-quality production activities in relation to them. Thus, the scholars who define these concepts have referred to competence as a specific, specific requirement for the readiness of the student in the educational process.

Competence, therefore, defines not only human activity, but also human self as a subject of activity. Professional communicative competence includes the following qualities necessary for any professional activity [6]:

- written and oral communication skills in business;

- ability to negotiate on the case;

- ability to communicate in accordance with work etiquette;

- Ability to interact with team members;

- Ability to establish constructive interpersonal relationships with colleagues, management and employees (communication with partners);

- ability to prevent and resolve conflicts;

- Ability to model and regulate their actions and the actions of the interlocutor in different business situations;

- readiness to solve professional and personal problems (decision-making, analysis, formulation, discussion and solution);

- the ability to listen and hear the interlocutor and some other skills.

The importance of communicative competence for the teacher is also important for professional activity, because the interaction of the two main subjects of the learning process - the teacher and the student - is mainly communication, and this is done through conversation. The communicative competence of the teacher, as well as the whole system of working relationships with colleagues, parents and other subjects of the learning process to achieve their goals in the context of working with students. Communication in the pedagogical field is characterized by a number of features that determine the structure of the teacher's communicative competence. First, in everyday work, the teacher's communicative competence is manifested by vocabulary, level of knowledge, skills and abilities, readiness to objectively assess the pedagogical situation, in this regard, to be able to provide specific pedagogical tasks necessary for its manifestation necessary. Such cases are many and very diverse. Here are some of them:

1) the state of acquaintance of teachers with students; 
2) interpretation, explanation of the topic understanding;

3) provision of basic scientific information;

4) assessment of student performance;

5) teacher error and other circumstances.

6) violation of behavioral norms (noise, loud speech, etc.);

Every pedagogical situation requires the teacher to have certain speech genres. Thus, for the first type of situation, it is necessary to master such genres as greeting, greeting, presentation. For the second group of situations - conversations, lectures, questions; for the third - orders, requirements, orders, incentives, advice, inquiries, assurances; the fourth is praise, compliment, approval, and so on.

At the current stage of development of society, the education system is undergoing significant changes due to changes in the model of cultural and historical development. No matter what reforms are made in the education system, they are still the responsibility of the participant - the teacher. The teacher is the key person in the implementation of various innovations. In order to successfully implement innovations (and one of the main ideas of modernization of education is the development of these competencies), a teacher must have the necessary level of professionalism to solve the tasks assigned to him in the new environment.

Communicative competence (Latin competens correct, capable) - means the ability to establish and maintain effective relationships with other people.

Communicative competence is defined as one of a teacher's core competencies. If the teacher does not have sufficient communicative competence, is not ready to flexibly manage the process of interaction in the educational process, it is impossible to introduce modern person-centered technologies (because the teaching profession is both variable and managerial). uses communication technologies, develops mutual understanding, etc.

The development of students' communicative competence can be considered as one of the ways of development and self-expression of participants in the learning process. Thus, communicative competence becomes one of the key components of a high level of professionalism that depends on personal success, competitiveness and personal satisfaction, as well as the quality of education. Active and effective listening is one of the main conditions for constructive communication.

There are the following types of communicative competence:

- by application: general and professional;

- In terms of quality: creative and reproductive;

- on specific features: competence of the listener and the speaker.

- One of the conditions of communicative competence is compliance with certain rules and requirements.

\section{Discussions AND RESUlts}

In order to form the communicative competence of students in the study of social sciences in the process of continuing education, we were able to identify in our practice the effective possibilities of models for the development of the typology of the professional position of the teacher:

1. Possibilities of the "Socrates" model. The teacher will gain a wide audience in the audience by organizing active discussions. Active discussion is based on individuality, the creation of an environment of constant intellectual competition, students are 
constantly trying to justify their views.

2. Features of the "group discussion" model. The discussion takes place mainly in pairs and in the air. For the teacher, the main aspect of the learning process is the establishment of pedagogical cooperation between students.

3. Features of the "skill" model. The teacher acts as an example, directing his every action to attract the attention of students.

4. Possibilities of the "Discipline" model. The teacher avoids any uncertainty, emphasizes the need, always analyzes any situation quickly and puts forward an acceptable idea that will be a positive solution. This method is important in pedagogical practice.

5. Features of the "Manager" model. An effective audience environment that encourages students' initiative and independence is one in which the teacher seeks to discuss with each student the meaning of the problem being addressed, quality control, and evaluation of the end result.

6. Possibilities of the model "Coach". The communication environment in the classroom is imbued with a spirit of interaction. In this case, the students are like players on the same team, where each is not important as an individual, but they can do a lot of work together. The main goal of the teacher is to inspire the efforts of the team members for the end result, great success and victory.

We believe that teachers should take a responsible and responsible approach to the development of students' communicative competence and follow the following in the classroom when conducting lessons:

1. "Constant readiness for communication". The presence of general and personal barriers to communication often leads to incomplete and misunderstood information by students.

2. "Clarity". The teacher should not use abstract phrases and words and should not use very uncommon terms.

3. "Systematization of actions". The teacher should not only control the structure of speech and communication, but also control facial expressions, gestures, intonation and behavior.

4. "Personal error". In communication, we must always assume that our own personal point of view may also be wrong. This prevents us from making serious mistakes.

5. "Place and time". If the delivery of a piece of information is done in a timely and optimal manner, the effectiveness of any piece of information will increase dramatically.

6. "Openness". Willingness to reconsider our point of view in new situations caused by controversial situations, the ability to accept and take into account the views of the interlocutor.

7. "Feedback". Ensuring that the main goal of the communication process is achieved is mutual understanding. The structure of communicative competence is divided into the following parts: communicative knowledge, communicative skills and communicative abilities.

\section{Communicative competence structure:}

- to understand what communication is, to know its types, stages of development;

- communicative methods and techniques, their actions, capabilities and limitations;

- effective methods against different people and different situations;

- the level of development of their communicative skills and methods, 
effective methods in their work.

\section{Communication skills structure:}

- ability to speak;

- Ability to combine external and internal appearances, to think, to overcome obstacles in the process of communication;

- interactive skills: ability to build communication on a democratic basis, create a comfortable emotional and mental environment, self-management, adherence to the rules of professional ethics and etiquette and these rules, the ability to actively listen;

- Socio-perceptual ability: the ability to adequately perceive and evaluate the partner's actions in communication, to determine his condition, desires and motives through gestures, to create a positive image of others as a person, to make a positive impression.

\section{Communication skills structure:}

- ability to make a socio-psychological forecast of the communicative situation with which communication is established;

- socio-psychological programming of the communication process based on the specifics of the communicative situation;

- implementation of socio-psychological management of communication processes in a communicative situation.

- Research methods. In line with the goals and objectives of our study, we used the following research methods to confirm the hypothesis put forward:

- General scientific methods: philosophical theoretical analysis, psychological, pedagogical, methodological literature, normative documents on the studied issues, analysis of pedagogical experience,

$$
\text { comparative analysis, classification, }
$$
content analysis, modeling.

- Empirical methods: surveys, tests, analysis of students' activities in the process of diagnosing the level of development of communicative competence, methods of expert evaluation, observation, pedagogical experience (identification and formation).

\section{Conclusion}

The following conclusions were drawn from the study:

1. The development of communicative competence in students in the system of continuing education also depends on the level of communicative competence of teachers.

2. The choice of pedagogical management method is determined by the flexibility and variability of pedagogical communication techniques, which are inextricably linked to the specific conditions, age and individual characteristics of students and their activities.

3. It is important to purposefully form the communicative competence of future professionals who are fluent in speech, able to independently and correctly choose the method of professional communication and activity, actively using the generalized psychological and pedagogical knowledge in their work. Suggestions. Based on the above conclusions, the following suggestions are made:

4. Organization of interaction between teachers and students in the classroom for the formation of communicative competence of students.

5. Organization of lessons, taking into account 
CURRENT RESEARCH JOURNAL OF PEDAGOGICS 2(5): 13-19, May 2021

DOI: https://doi.org/10.37547/pedagogics-crjp-02-05-03

ISSN 2767-3278

(C)2021 Master Journals

Crossref dof 81 Google

Accepted 15th May, 2021 \& Published 20 th May, 2021

the age and individual characteristics of students, their ability to master the material.

6. The use of more communication techniques in the conduct of lessons, the creation of an environment of mutual intellectual competition between students.

7. Organize collaborative communication of students in the performance of written and oral assignments in the classroom.

8. To be able to communicate sincerely with all participants of the educational process, including students, to listen to them, to have a positive impact on them.

9. Preparing students to independently organize professional and pedagogical activities.

10. To prepare students to be able to think independently, to realize their inner potential in the classroom.

\section{REFERENCES}

1. Ўзбекистон Республикаси Президентининг 2017 йил 7 февралдаги “ўзбекистон Республикасини янада ривожлантириш бўйича Харакатлар стратегияси тўғрисида"ги ПФ-4947-сонли Фармони. - https://lex.uz/docs/3107036

2. Ашихмина Т.А. Формирование коммуникативной компетентности студентов // Мир науки, культуры, образования .-2012.- №4(35).-с. 52-54.

3. Зеер Э.Ф. Модернизация профессионального образования: компетентностный подход // Образование и наука. Известия. Урал. отделение РАО. 2004. - № 3. - С. 42-53.

4. Лукъянова М.И. Психологопедагогическая компетентность учителя // Москва, Педагогика. - 2001. - № 10. - с. 56-61.
5. Муслимов Н.А. Бўлажак касб таълими ўқитувчиларини касбий шакллантириш. Монография. - Т.: “Фан”, 2004. - 126 б.

6. Шарипов Ш.С. Касбий таълим педагогикаси. - Т.: ТДПУ, 2005.-54 б.

7. Siddikov, I., \& Gulomov, A. (2020). Philosophical and psychological features of the formation of asertive behavior in the development of cognitive activity. In Психологическое здоровье населения как важный фактор обеспечения процветания общества (pp. 38-42).4

8. Сиддиков, И. Б. (2019). Государственная политика в отношении молодежи в Узбекистане: национальный опыт и реальная необходимость международных инициатив. In Условия социальноэкономического развития общества: история и современность (рp. 38-43). 